\title{
Production, Characterization And Application Of Inulinase From Pseudozyma Sp. CCMB 300
}

\author{
Diego Sampaio Nascimento ${ }^{1}$, Danyo M. Lima ${ }^{1}$; Gildomar Valasques Junior ${ }^{1}$, Rodrigo de \\ Queiroz Oliveira ${ }^{1}$, Pedro Fernandes ${ }^{3}$; Rita de Cássia L. Figueiredo Ribeiro ${ }^{4}$, Ana Paula \\ Trovatti Uetanabaro ${ }^{2}$, Aristóteles Góes-Neto ${ }^{2}$; Sandra A. Assis ${ }^{1 *}$ \\ ${ }^{1}$ Laboratório de Enzimologia e Tecnologia de Fermentação; Departamento de Saúde; Universidade Estadual \\ de Feira de Santana (UEFS), BA, Brazil. \\ diegouefs@hotmail.com; danyo.lima@bol.com.br; jrvalasques@gmail.com; \\ rodrigodeqo@yahoo.com.br \\ ${ }^{2}$ Laboratório de Pesquisa em Microbiologia; Departamento de Ciências Biológicas; Universidade Estadual de \\ Feira de Santana (UEFS), BA, Brazil. \\ arigoesneto@yahoo.com.br; uetanabaro@yahoo.com \\ ${ }^{3}$ IBB, Institute for Biotechnology and Bioengineering, Centre for Biological and Chemical Engineering, Instituto \\ Superior Técnico,1049-001Lisboa,Portugal. \\ pedroefe@yahoo.com \\ Rita de Cássia L. Figueiredo Ribeiro <ritarib@usp.br>; \\ ${ }^{4}$ Instituto de Botânica, Caixa Postal 3005, CEP 01061-970 São Paulo, SP. \\ ritarib@usp.br \\ *Corresponding author: sandrinhaassis@yahoo.com.br
}

\section{ABSTRACT}

The use of inulinases provides an alternative way to obtain fructose syrup through the hydrolysis of inulin. The objective of this work was to study the production, characterization and application of an inulinase from Pseudozyma sp CCMB 300 isolated from Brazilian semi-arid region. The higher production of inulinase in a medium containing $0.86 \mathrm{~g} \mathrm{~L}^{-1}$ yeast extract and $14.54 \mathrm{~g} \mathrm{~L}^{-1}$ glucose using response surface methodology (RSM). This statistical method was also used to access the optimum $\mathrm{pH}(8.28)$ and temperature (54을 for fermentative inulinase production. The results showed that the inulinase has potential for inulin hydrolysis, where a conversion yields of roughly $87.39 \%$ for an initial concentration of inulin of $1 \%(\mathrm{w} / \mathrm{v})$.

\section{Keywords:}

Inulin, inulinase, yeasts, semi-arid, fructose.

\section{Academic Discipline and Sub-Disciplines}

Biotechnology

Subject Classification

Microbiology

\section{Council for Innovative Research}

Peer Review Research Publishing System

\section{Journal: JOURNAL OF ADVANCES IN BIOTECHNOLOGY}

Vol. 4, No. 2.

www.cirjbt.org , jbteditor@gmail.com 


\section{INTRODUCTION}

The enzyme inulinase (EC 3.2.1.7) target the $\beta$-2 linkage of inulin, a polyfructan consisting of linear $\beta-2,1$ linked fructose, and hydrolyzes it into fructose [1].

Inulin is a naturally occurring polyfructan in plants consisting of linear chains of $\beta(2,1)$-linked fructose residues attached to a terminal sucrose molecule. It is produced naturally in over 36,000 plants world wide, including 1200 native grasses and cereals belonging to several genera. In addition, inulin has extensive documented historical human use through the consumption of edible plants and fruits [2].

Inulinase can be derived from plants and many microorganisms. Dandelion, chicory and Jerusalem artichoke have been proven to contain inulinase that can be purified, but according to Kochhar and Kanur [3], these sources are not as productive as the microbial one, which seem to be the only source capable of producing enough enzymes for industrial applications. For this reason, in the last three decades, significant efforts have been made to find the best microbial source for the extraction of inulinase [4].

Conventional fructose production from starch needs at least three enzymatic steps, including a-amylase, amyloglucosidades, and glucose isomerase action, yielding only $45 \%$ fructose solutions. More concentrated fructose solution requires a dedicated chromatographic step. A viable alternative to this process is the hydrolysis of inulin by inulinases. Enzymatic formation of fructose from inulin has a single enzymatic step and yields up to 95\% fructose[5].

The Brazilian semi-arid region represents a large area for bioprospection since naturally occurring microorganisms adapted to a tropical semi-arid environment, with high temperature and low humidity throughout the year, may possess some features of great industrial interest [6]

In this study, we carried out a survey of the production, characterization and application of extracellular inulinases produced by Pseudozima sp. from the Brazilian semi-arid region.

\section{MATERIALS AND METHODS}

\section{Chemicals}

Inulin, bovine serum albumin, and 3,5-dinitrosalicylic acid were purchased from Sigma Chemical Co. (St Louis, MO, USA). All the other chemicals used were also of high-quality analytical grade.

\section{Microorganisms}

The yeast strains Pseudozyma sp. CCMB is from Culture Collection of Microorganisms of Bahia (CCMB) of the Universidade Estadual de Feira de Santana, Brazil (Uetanabaro and Góes-Neto 2006) and was identified in our previous work [7].

The yeast strains were maintained in YM agar (3\% yeast extract $(\mathrm{w} / \mathrm{v}), 3 \%$ malt extract $(\mathrm{w} / \mathrm{v}), 5 \%$ peptone $(\mathrm{w} / \mathrm{v}), 10 \%$ glucose (w/v), and $20 \%$ agar (w/v), $\mathrm{pH} 6.2)$.

\section{Inulinase production}

The yeast was previously grown on YM agar at $28^{\circ} \mathrm{C}$ for $48 \mathrm{~h}$, as described in Oliveira (2007), diluted in sterile distilled water to a concentration of about $10^{8}$ colony-forming units $/ \mathrm{ml} .10 \%(\mathrm{v} / \mathrm{v})$ of the diluted growth medium was inoculated in flasks containing (per $1 \mathrm{~L}$ ) mineral medium $\left(\mathrm{CaCl}_{2}, 0.25 \mathrm{~g} ;\left(\mathrm{NH}_{4}\right)_{2} \mathrm{SO}_{4}, 3 \mathrm{~g} ; \mathrm{KH}_{2} \mathrm{PO}_{4}, 4.5 ; \mathrm{MgSO}_{4}, 0.25 \mathrm{~g}\right)$, supplemented with yeast extract, $1 \mathrm{~g}$; glucose, $10 \mathrm{~g}$; pH 5.0, for fermentation. ${ }^{8}$ After incubation at $28{ }^{\circ} \mathrm{C}$ for $48 \mathrm{~h}$ in an orbital shaker at $150 \mathrm{rpm}$, the cells were separated by centrifugation at $10,000 \mathrm{~g}$ for $10 \mathrm{~min}$ at $48 \stackrel{\circ}{\circ}$, and the supernatant liquid media was used as the extracellular fraction.

\section{Biomass quantification}

The cells, which were previously separated by centrifugation, were used to determine the dry weight at $50^{\circ} \mathrm{C}$.

\section{Enzyme assays}

Inulinase activity was measured spectrophotometrically using the dinitrosalicylic reagent, as reported by Miller [8]. The reaction mixture consisted of $900 \mu \mathrm{L}$ of $2 \%(\mathrm{w} / \mathrm{v})$ inulin in $0.05 \mathrm{M}$ acetate buffer, $\mathrm{pH} 5.5$, and 100 _I culture supernatant. The mixture was incubated for $15 \mathrm{~min}$ at $50 \stackrel{\circ}{\circ}$. After incubation, $1 \mathrm{~mL}$ dinitrosalicylic reagent was added, and the mixture was boiled at $100^{\circ} \mathrm{C}$ for $10 \mathrm{~min}$ and cooled with $10 \mathrm{~mL}$ distilled water. One unit of enzyme activity of inulinase was defined as the amount of the enzyme that catalyzed the formation of $1 \mu \mathrm{mol}$ fructose/min.

\section{Protein determination}

Total protein determination was performed according to Bradford [10], using bovine serum albumin as the standard. 


\section{Doehlert experimental design for enzyme production}

The Doehlert experimental design, with two variables (concentration of glucose and yeast extract) and three replicates at the centre of the domain leading to a total of 9 experiments (Table 1) was used to obtain the knowledge of the effect of glucose and yeast extract concentration on the production of enzyme.

Table 01: Results of the factorial analysis for inulinase production CCMB 300

\begin{tabular}{ccccc}
\hline $\mathbf{N}^{\circ}$ & $\begin{array}{c}\text { Concentration } \\
\text { of glucose (g/L) }\end{array}$ & $\begin{array}{c}\text { Concentration of } \\
\text { yeast extract (g/L) }\end{array}$ & $\begin{array}{c}\text { Experimental } \\
\text { values } \\
\text { (UA) }\end{array}$ & $\begin{array}{c}\text { Activities } \\
\text { predicted } \\
\text { (UA) }\end{array}$ \\
\hline 1 & $7.5(-0.5)$ & $1.5(+0.866)$ & 1.0242 & 1.0409 \\
2 & $12.5(+0.5)$ & $1.5(+0.866)$ & 1.7904 & 1.7736 \\
3 & $5(-1)$ & $1(0)$ & 1.3198 & 1.3030 \\
$4 \mathrm{C}$ & $10(0)$ & $1(0)$ & 2.3734 & 2.3935 \\
$4 \mathrm{C}$ & $10(0)$ & $1(0)$ & 2.4376 & 2.3935 \\
$4 \mathrm{C}$ & $10(0)$ & $1(0)$ & 2.3697 & 2.3935 \\
5 & $15(+1)$ & $1(0)$ & 2.6988 & 2.7155 \\
6 & $7.5(-0,5)$ & $0.5(-0.866)$ & 1.7022 & 1.7189 \\
7 & $12.5(-1)$ & $0.5(-0.866)$ & 2.4155 & 2.3987 \\
\hline
\end{tabular}

Thus, concentration of glucose was studied in 5 levels $\left(7.5\right.$ to $\left.12.5 \mathrm{~g} \mathrm{~L}{ }^{-} 1\right)$ and yeast extract was studied in three levels $(0.5$ to $\left.1.5 \mathrm{~g} \mathrm{~L}{ }^{-1}\right)$. The experimental errors were evaluated from replication of central point. The experimental data were processed by using the STATISTICA software. All the experiments in this step were carried out in random order.

To estimate the lack of fit of the model to the experimental data an analysis of variance (ANOVA) was performed (Table 2), using Design Statistics, version 7.0.

Table 02 Analysis of variance

\begin{tabular}{ccccccc}
\hline Variation source & SQ & gl & MQ & F & $\begin{array}{c}\text { Tabulated F } \\
\text { (IC de 95\%) }\end{array}$ & $\mathbf{R}^{2}$ \\
\hline Regression & 2.669513 & 5 & 0.533903 & 348.3017 & 9.01 \\
Residual & 0.004599 & 3 & 0.001533 & & & 0.99 \\
Lack of Fit & 0.001683 & 1 & 0.001683 & 1.155 & 0.394970 & \\
Pure Error & 0.002915 & 2 & 0.001458 & & & \\
Total SQ & 2.674111 & 8 & & & \\
\hline
\end{tabular}

\section{Response surface optimization of temperature and pH}

Response surface modeling was applied to cultures of yeast, to determine the optimum temperature and $\mathrm{pH}$ for inulinases obtained. This statistical technique for experimental design has advantages over methods that investigate only one variable at a time.

The experimental design, with two variables (temperature and $\mathrm{pH}$ ) and three replicates at the centre of the domain leading to a total of 9 experiments (Table 3) was used to obtain the knowledge of the effect of temperature and $\mathrm{pH}$ of inulinase activity. 
Table 03. Results of the factorial for optimization of temperature and pH CCMB 300

\begin{tabular}{ccccc}
\hline $\mathbf{N}^{\circ}$ & $\mathbf{p H}$ & Temperature ${ }^{\circ} \mathbf{C}$ & $\begin{array}{c}\text { Experimental values } \\
\text { (UA) }\end{array}$ & \multicolumn{2}{c}{$\begin{array}{c}\text { Activities predicted } \\
\text { (UA) }\end{array}$} \\
\hline $\mathbf{1}$ & $6(-0.5)$ & $70(+0.866)$ & 1.5104 & 1.5743 \\
$\mathbf{2}$ & $8(+0.5)$ & $70(+0.866)$ & 1.9197 & 1.8557 \\
$\mathbf{3}$ & $5(-1)$ & $50(0)$ & 1.8427 & 1.7787 \\
$\mathbf{4 C}$ & $7(0)$ & $50(0)$ & 2.1973 & 2.2147 \\
$\mathbf{4 C}$ & $7(0)$ & $50(0)$ & 2.2279 & 2.2147 \\
$\mathbf{4 C}$ & $7(0)$ & $50(0)$ & 2.2189 & 2.2147 \\
$\mathbf{5}$ & $9(+1)$ & $50(0)$ & 2.1971 & 2.2610 \\
$\mathbf{6}$ & $6(-0.5)$ & $30(-0.866)$ & 1.0458 & 1.1097 \\
$\mathbf{7}$ & $8(+0.5)$ & $30(-0.866)$ & 1.3744 & 1.3104 \\
\hline
\end{tabular}

The $\mathrm{pH}$ was studied in 5 levels ( 5 to 9 ) and temperature was studied in three levels (30 to $70^{\circ} \mathrm{C}$ ). The experimental errors were evaluated from replication of central point. The experimental data were processed by using the STATISTICA software. All the experiments in this step were carried out in random order.

To estimate the lack of fit of the model to the experimental data an analysis of variance (ANOVA) was performed, using Design Statistica, version 7.0.

\section{Effect of cations}

The effect of $\mathrm{Na}^{+}$and $\mathrm{K}^{+}$on inulinase activity was studied. The concentrations used were: $\mathrm{NaCl}(0.05,0.1,0.15,0.2,0.25$ and $0.3 \mathrm{~mol} / \mathrm{L}), \mathrm{KCl}(0.05,0.1,0.15,0.2,0.25$ and $0.3 \mathrm{~mol} / \mathrm{L})$. The inulinase activity was determined by the standard assay as described previously.

\section{Determination of kinetics Parameters}

To obtain the parameters of the Michaelis-Menten kinetics of inulinase for the hydrolysis of inulin, $\mathrm{K}_{m}$ and $\mathrm{V}_{\text {max }}, 0.9 \mu \mathrm{L}$ inulin $(1,1.5,2.0,2.5$ and $3.0 \% \mathrm{w} / \mathrm{v})$ was added to $100 \mu \mathrm{L}$ of inulinase in $0.05 \mathrm{M}$ acetate buffer (pH 5.5) and incubated at $50 \stackrel{\circ}{ } \mathrm{C}$ for $15 \mathrm{~min}$. The $\mathrm{K}_{\mathrm{m}}$ and $\mathrm{V}_{\max }$ for inulin was determined by the method of Lineweaver-Burk plots.

\section{Hydrolysis of inulin}

The extent of inulin hydrolysis (\%) was calculated as $\frac{\text { amount of fructose released }}{\text { amount of initial totalsugars }} \times 100$ [11]. Total sugars were determined by antrone method and reducing sugars were determined by the dinitrosalicylic acid method (Miller, 1959). The Doehlert experimental design, with two variables (concentration of enzyme and fermentation time) and three replicates at the centre of the domain leading to a total of 9 experiments (Table 4) was used to obtain the knowledge of the effect of enzyme concentration and fermentation time on the extent of inulin hydrolysis from a solution $1 \%(\mathrm{w} / \mathrm{v}) \mathrm{in}$ citrate buffer $0.05 \mathrm{M}$.

\section{Statistical analysis}

All experiments were carried out in triplicate. One-way analysis of variance was used to compare the specific activity of inulinase among the strains. Where significant differences were detected between strains, the means were compared using Tukey's test. For all statistical analyses, the level of significance was set at $5 \%$, and the analyses were performed using the standard statistical software SPSS for Windows (release 6.1.3, 1995; SPSS, Brazil, 1995).

\section{Results and Discussion}

\section{Production of inulinases by yeasts}

The table 01 shows the Doehlert design applied to optimize the production of inulinase by Pseudozyma sp. CCMB 300. The first column describes the number of planning, with $\mathrm{C}$ representing the central compound. In the second and third column are the values of glucose concentration and the concentration of yeast extract, respectively. The fourth column represents the enzymatic activity. The last column represents predicted 
The response surface graphics (Figures 01 and 02) shows the influence of glucose and yeast extract concentrations in the production of inulinase of CCMB 300. From the analysis of the area chart in Figures 01 and 02 it can be concluded that the production of inulinase by CCMB 300 strains clearly peaks for glucose concentrations in excess of $10 \mathrm{~L}^{-1} \mathrm{~L}$ glucose, for the whole range of concentration of yeast extract tested.

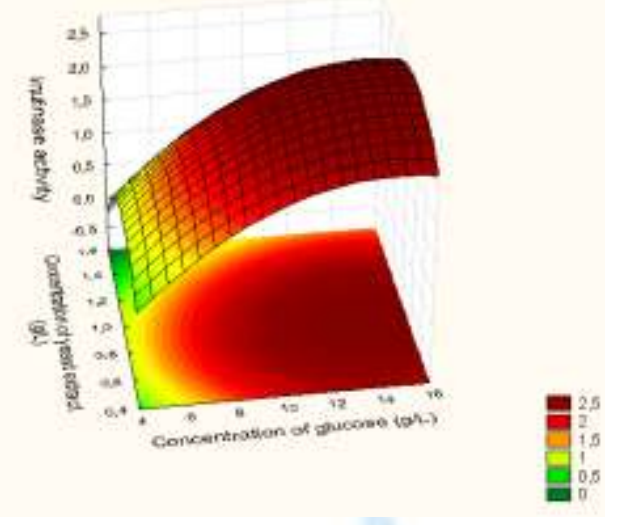

Fig. 01. Response surface for yeast extract concentration versus glucose concentration CCMB 300

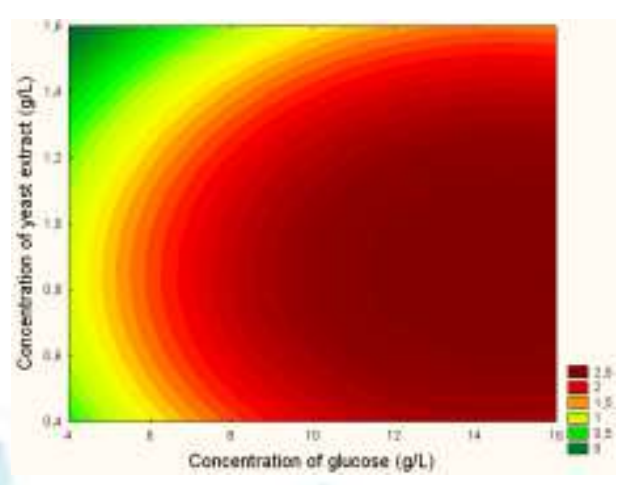

Fig. 02. Level curves for yeast extract concentration versus glucose concentration CCMB 300

Equation 1 illustrates the relation of these two variables and the enzyme activity (UA), where G is the glucose concentration $\mathrm{g} / \mathrm{L}$ and $\mathrm{YE}$ is the yeast extract concentration $\mathrm{g} / \mathrm{L}$.

$$
(U A)=-2.056+0,438(G)-0.0153(G) 2+3.758(Y E)-2.258(Y E) 2+.0106(G) X(Y E) \text {. }
$$

(Equation 1)

Through the derivation of this equation, the media composition, regarding glucose and yeast extract concentrations, which are expected to allow for the production of maximum enzymatic activity, can be obtained. For CCMB 300 the conditions are $14.54 \mathrm{~g} \mathrm{~L}^{-1}$ for glucose and $0.86 \mathrm{~g} \mathrm{~L}^{-1}$ for yeast extract.

Different nitrogen sources were studied for Cryptococccus aureus inulinases. Yeast extract was the better and increased inulinase production [12]. According to these authors, vitamins and trace elements present in the yeast extract may enhance inulinase production.

The chart of Paretto (Figure 03) shows that both linearly $(L)$ and quadratically $(Q)$, the variables glucose concentration and yeast extract concentration are significant for the production of inulinase by Pseudozyma CCMB 300, because both variables had a $p$ value greater than 0.05 .

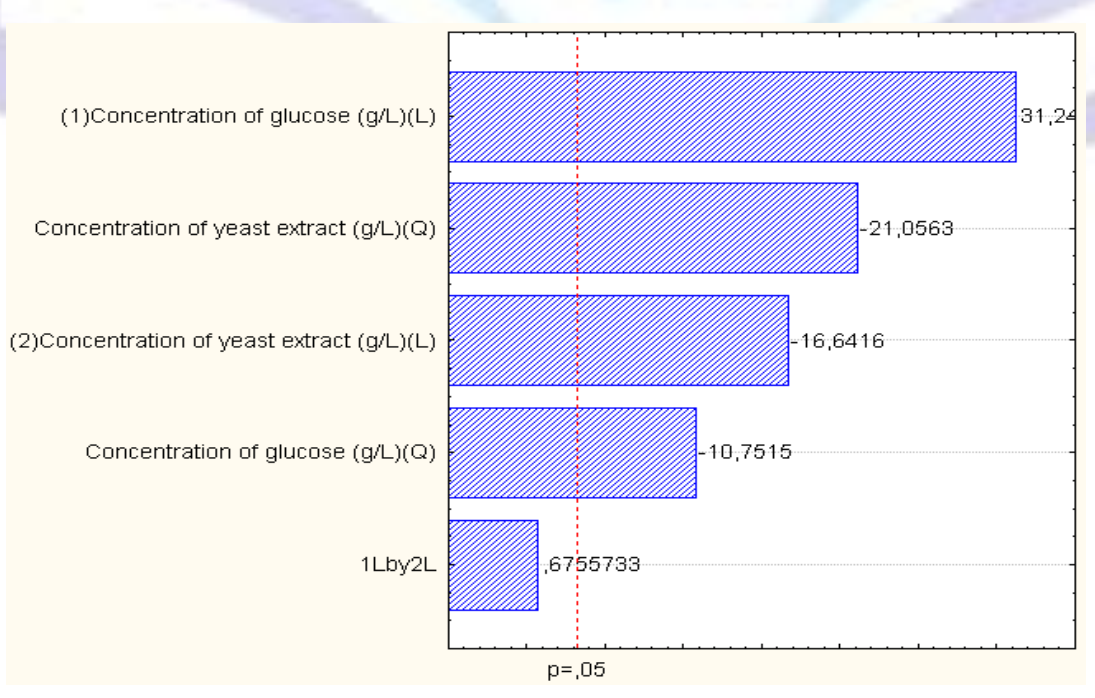

Figure 03. Pareto Chart for inulinase production CCMB 300 
The statistical significance of the regression (Table 02) can be assessed by the ratio of the mean square regression and mean square of the residue and by comparing these sources of variation using the Fisher distribution ( $F$ test) Thus, a statistically significant value of this ratio must be greater than the tabulated value for $F$. It is obtained by the ANOVA table that calculated $F(348.30)$ is higher than the F tabulated (9.01) showing that the function is well suited to the answers.

\section{Response surface optimization of temperature and $\mathrm{pH}$}

The table 03 shows the Doehlert design applied to the optimization of temperature and $\mathrm{pH}$ inulinase obtained by Pseudozyma sp. CCMB 300.

The influence of temperature and $\mathrm{pH}$ on the activity of the enzyme was investigated for CCMB 300 by surface response methodology. The results are shown in Figures 04 and 05.

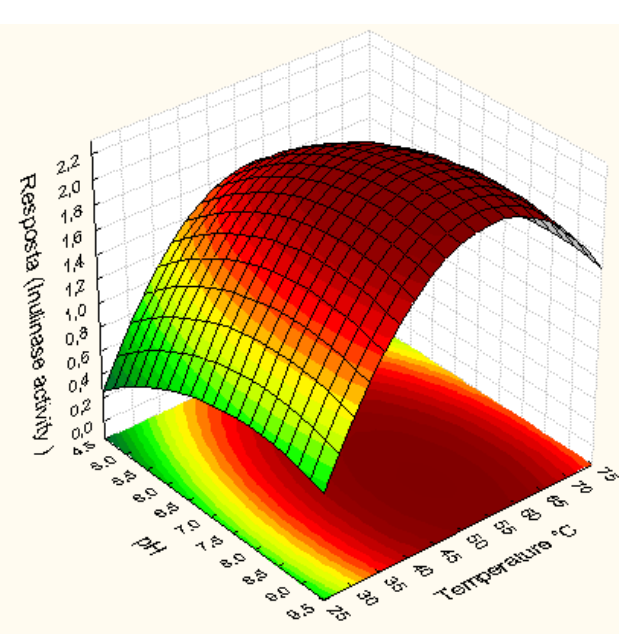

Fig 04. Response surface for $\mathrm{pH}$ versus temperature

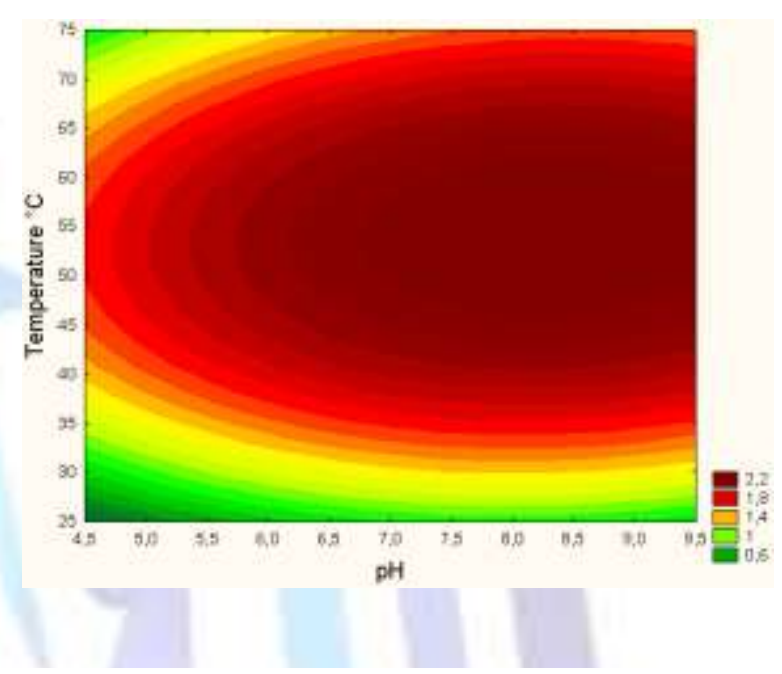

Fig 05. Level curves for $\mathrm{pH}$ versus temperature

The regression model provided for the enzyme activity in relation to $\mathrm{pH}$ and temperature in the experimental design is expressed by Equation 2:

$$
(U A)=-5.6887+0.7514(P)-0.0486(P) 2+0.1814(T)-0.00175(T) 2+0.00101(P) .(T) \text {. }
$$

\section{(Equation 2)}

This equation illustrates the relationship of these two variables with enzyme activity (UA), where: $\mathrm{P}$ is the $\mathrm{pH}$ and $\mathrm{T}$ is the temperature ${ }^{\circ} \mathrm{C}$. Through the derivation of this equation, the points of maximum enzymatic activity can be obtained. According to this methodology, the optimal $\mathrm{pH}$ and temperature values were of 8.28 and $54^{\circ} \mathrm{C}$, respectively.

Many works in the literature deal with the effects of temperature and $\mathrm{pH}$ on inulinase activity. It is certain that the response of the enzyme activity to these variables depends mainly on the strain used as a source for enzyme production. The studies of Pandey et al[13] showed that fungal inulinases exhibited an optimum pH between 4.5 and 7.0, yeasts inulinases between 4.4 and 6.5 and bacterial inulinases between 4.8 and 7.0. Inulinases preparations from $A$. niger strains have also been shown to have $\mathrm{pH}$ and temperature optima in the ranges of 4.35 to 5.35 and 45 to $60^{\circ} \mathrm{C}$ [14] Information about the effect of temperature and $\mathrm{pH}$ on inulinase activity is very important for assessing the feasibility industrial application, and to the development of bioprocesses and to the selection of bioreactors.

The Paretto chart (Figure 06) shows that both linearly and quadratically, temperature and $\mathrm{pH}$ are exerting influence on the enzyme activity of inulinase Pseudozyma CCMB 300, because both variables had a $p$ value greater than 0.05. 


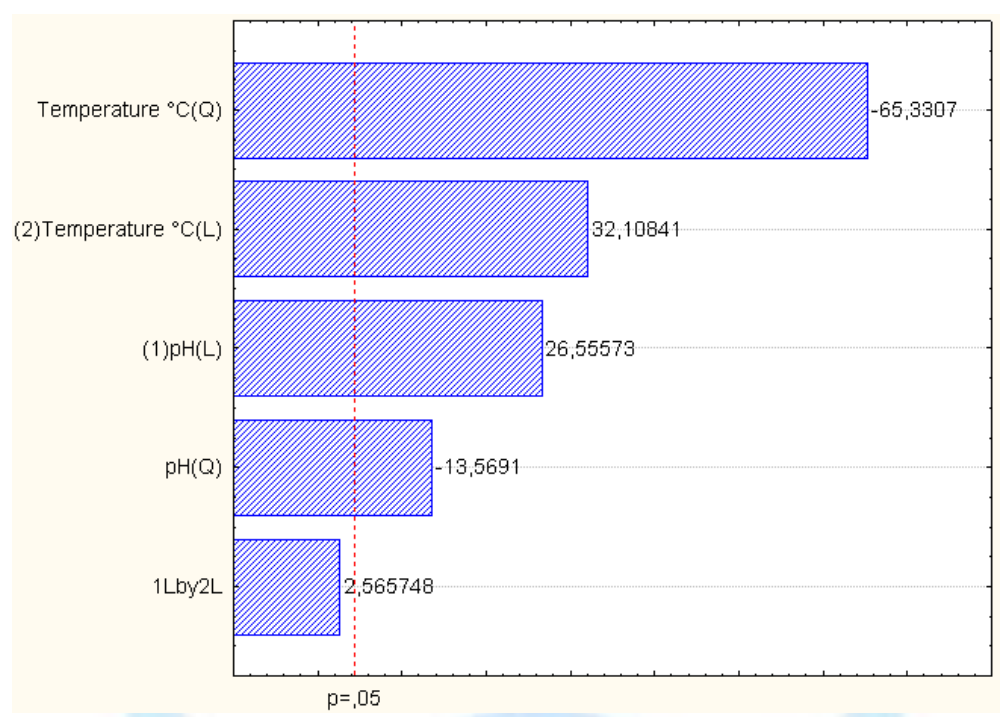

Fig. 06. Paretto Chart

The statistical significance (Table 04 ) of the regression can be assessed by the ratio of the mean square regression and mean square of the residue and by comparing these sources of variation using the Fisher distribution ( $F$ test) Thus, a statistically significant value of this ratio must be greater than the tabulated value for $F$. It is obtained by the ANOVA table that calculated $F(35.67)$ is higher than the $F$ tabulated (9.01) showing that the function is well suited to the answers.

Table 04 Analysis of variance

\begin{tabular}{ccccccc}
\hline Variation source & SQ & gl & MQ & F & $\begin{array}{c}\text { Tabulated } \\
\mathbf{F}\end{array}$ & $\mathbf{R}^{2}$ \\
\hline (IC de 95\%) & & & & \\
\hline Regression & 1.486667 & 5 & 0.297333 & 35.67048 & & \\
Residual & 0.025007 & 3 & 0.008336 & & 0.009940 \\
Lack of Fit & 0.024512 & 1 & 0.024512 & 99.111 & & \\
Pure Error & 0.000495 & 2 & 0.000247 & & & \\
Total SQ & 1.511674 & 8 & & & & \\
\hline
\end{tabular}

\section{Effect of cations}

The effect of salts $\mathrm{NaCl}$ and $\mathrm{KCl}$ on the activity of inulinase are shown in Figure 07 . The activity was maximal at a concentration of $0.15 \mathrm{~mol} / \mathrm{L}$ of $\mathrm{NaCl}$ and KCl. Thconcentrations of $0.15 \mathrm{~mol} \mathrm{~L}^{-1}$ of NaCl and KCl increased the activity of inulinase from CCMB 300 by approximately $40 \%$. When concentration higher than $0.15 \mathrm{~mol} \mathrm{~L}^{-1}$ were used, a decrease in the activity of the enzyme was observed. 


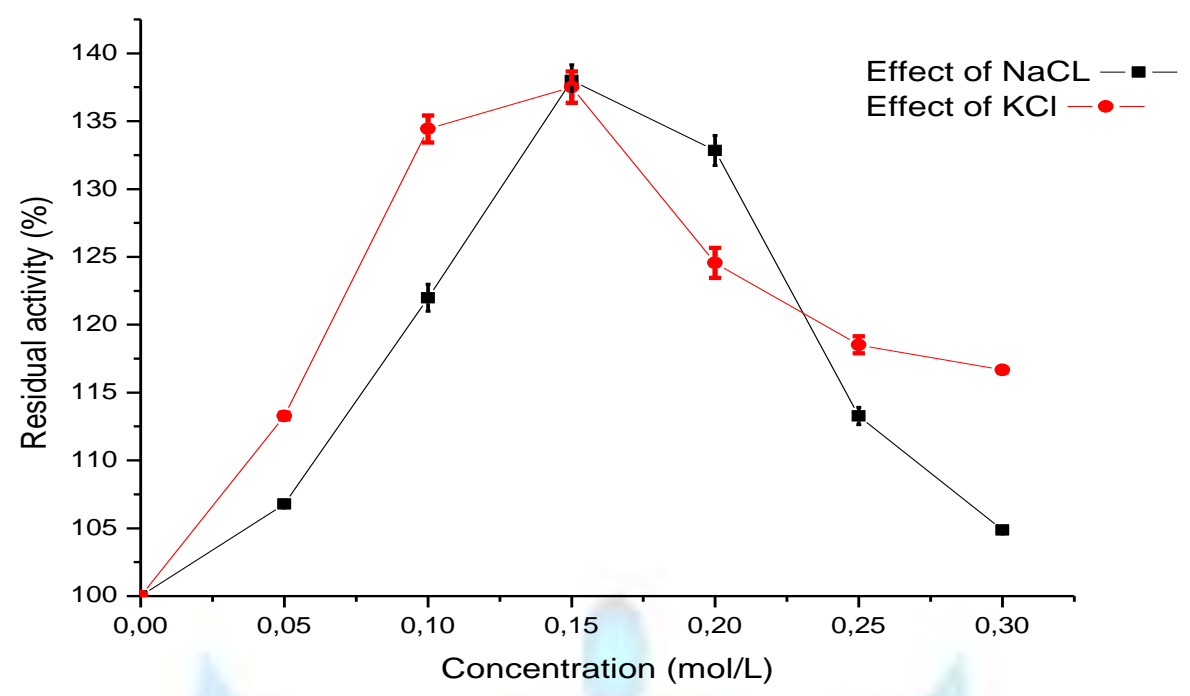

Fig. 7. Effect of salts on CCMB 300 inulinase activity

\section{Kinetics Parameters}

The Lineweaver-Burk plot showed that the $K_{m}$ and $V_{\max }$ values of the enzyme for inulin were $23 \mathrm{mg} / \mathrm{mL}$ and 28.33 $\mu \mathrm{mol} / \mathrm{mL}$.min, respectively (Fig. 08). These results demonstrate that the inulinase from CCMB 300 displayed affinity for inulin and are in agreement with other studies. The $\mathrm{K}_{\mathrm{m}}$ value for inulinase from Aspergillus ficuum JNPSP was $25.6 \mathrm{mg}$ $\mathrm{mL}^{-1}[15]$.

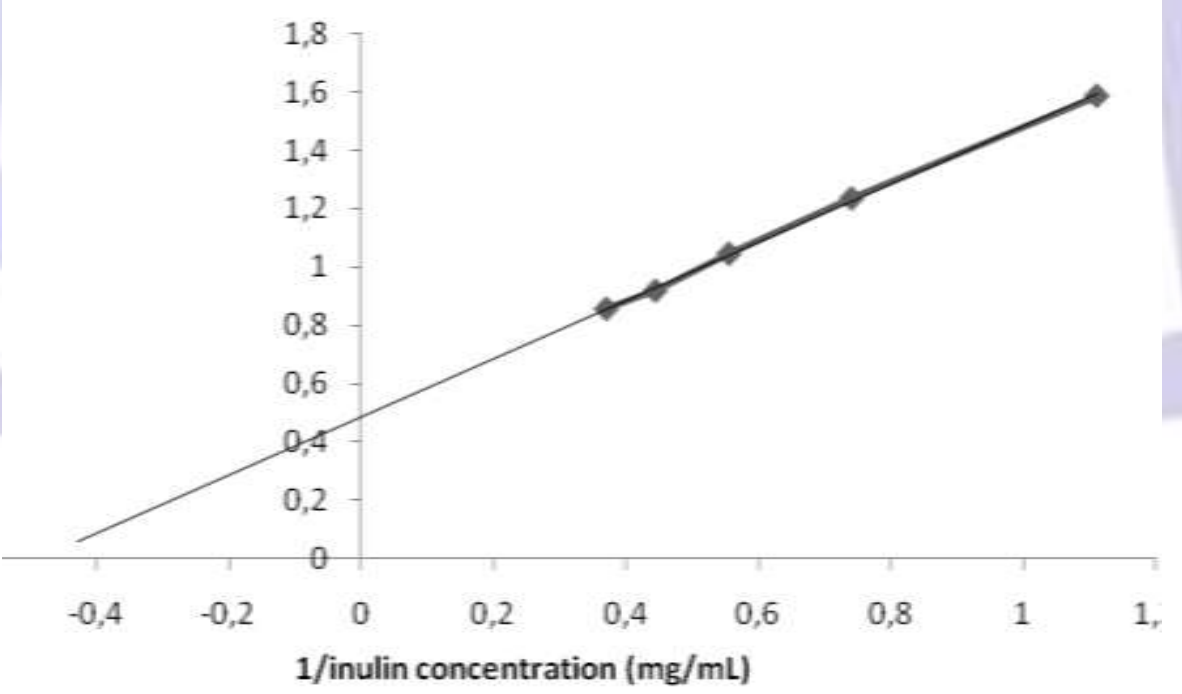

Fig. 08. Influence of substrate concentration on the inulinase activity

\section{Hydrolysis of inulin}

The Table 05 shows the Doehlert design applied to optimize the hydrolysis in function of time of reaction and enzyme concentration of inulin by Pseudozyma sp. CCMB 300 inulinase. 
Table 05: Results of the factorial for inulin hydrolysis

\begin{tabular}{ccccc}
\hline $\mathbf{N}^{\circ}$ & $\begin{array}{c}\text { Enzyme } \\
\text { Concentration } \\
(\% \mathbf{~ v / v )}\end{array}$ & Time (min) & $\begin{array}{c}\text { Experimental values } \\
\text { (\% Hidrolysis) }\end{array}$ & $\begin{array}{c}\text { Response } \\
\text { predicted } \\
\text { (\% Hidrolysis) }\end{array}$ \\
\hline $\mathbf{1}$ & $5(+0.866)$ & $4.5(-0.5)$ & 64.543 & 63.12755 \\
$\mathbf{2}$ & $5(+0.866)$ & $12.5(+0.5)$ & 49.7088 & 51.12425 \\
$\mathbf{3}$ & $3(0)$ & $1(-1)$ & 51.6736 & 53.06016 \\
$\mathbf{4 C}$ & $3(0)$ & $8(0)$ & 87.0309 & 87.38700 \\
$\mathbf{4 C}$ & $3(0)$ & $8(0)$ & 88.5784 & 87.38700 \\
$\mathbf{4 C}$ & $3(0)$ & $8(0)$ & 86.0895 & 87.38700 \\
$\mathbf{5}$ & $3(0)$ & $15(+15)$ & 51.0665 & 49.21775 \\
$\mathbf{6}$ & $1(-0.866)$ & $4.5(-0.5)$ & 48.6767 & 47.26125 \\
$\mathbf{7}$ & $1(-0.866)$ & $12.5(+0.5)$ & 41.6217 & 43.03715 \\
\hline
\end{tabular}

The hydrolysis was studied in five levels ( 1 to 12.5 minutes) and enzyme concentration was studied in three levels ( 1 to 5 $\%$ ) (Figure 09 and 10).The experimental data were processed by using the STATISTICA software. All the experiments in this step were carried out in random order.

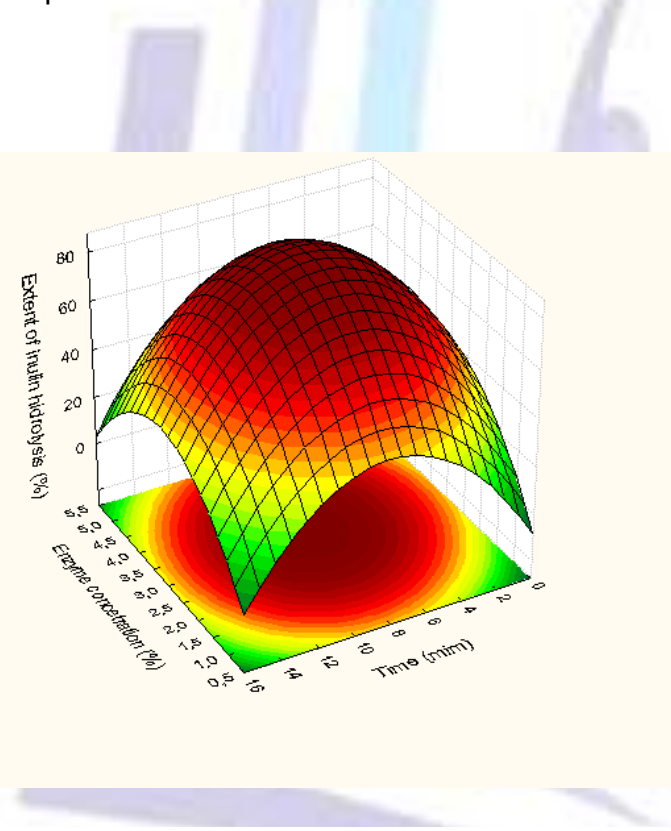

Fig. 09. Response surface for hydrolysis of inulin

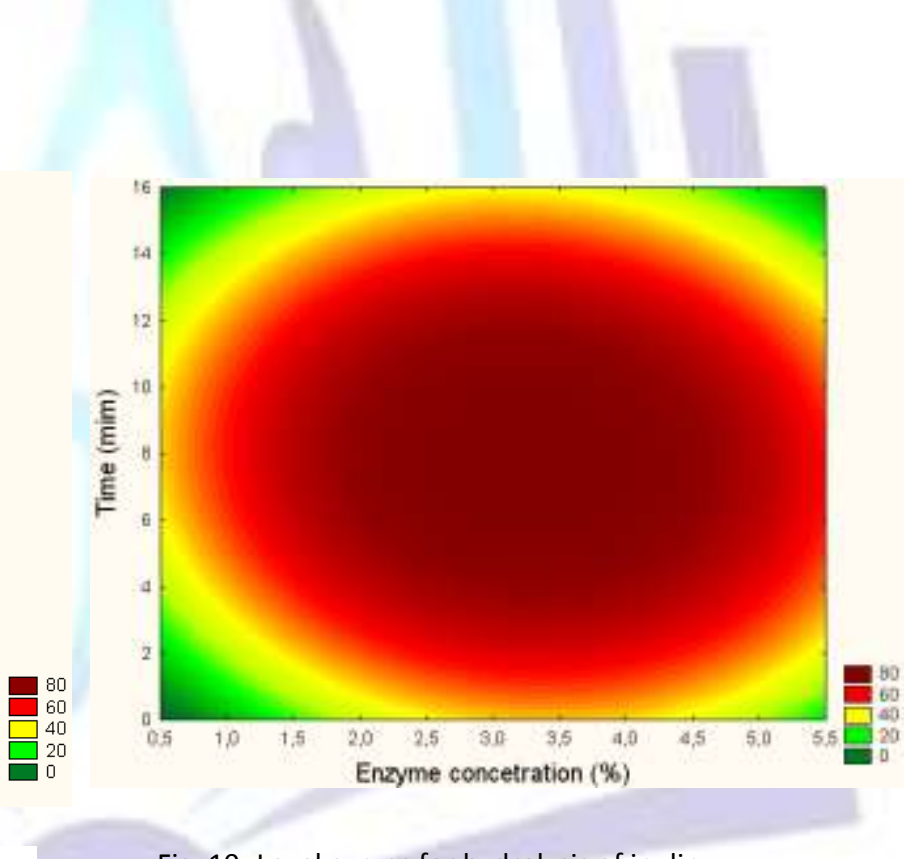

Fig. 10. Level curves for hydrolysis of inulin

Equation 3 illustrates the relation of these two variables with the extent of hydrolysis (\% $\mathrm{H})$, where: $\mathrm{C}$ is the enzyme concentration $(\% \mathrm{v} / \mathrm{v})$ and $\mathrm{T}$ is the time $(\mathrm{min})$.

$$
\left.\% \mathrm{H}=-27.148+41.197(\mathrm{C})-6.0227(\mathrm{C})^{2}+12.291(\mathrm{~T})-0.739(\mathrm{~T})^{2}-0.2431(\mathrm{C})(\mathrm{T}) \text { (Equation } 3\right)
$$

Through the derivation of this equation, the points of maximum enzymatic activity are obtained. In this work the highest productivity, based on the extent of hydrolysis, was observed for $3.26 \%$ of enzyme and 7.7 minutes of incubation. The higher conversion yields was $87.39 \%$. There are few studies of inulin hydrolysis using the same conditions and SRM analysis, as performed in this work.

The Paretto chart (Figure 11) shows that both linearly and quadratic, variables: enzyme concentration and time of hydrolysis are significant for the hydrolysis of inulin Pseudozyma sp CCMB 300, because both variables has a value greater than 0.05 . 


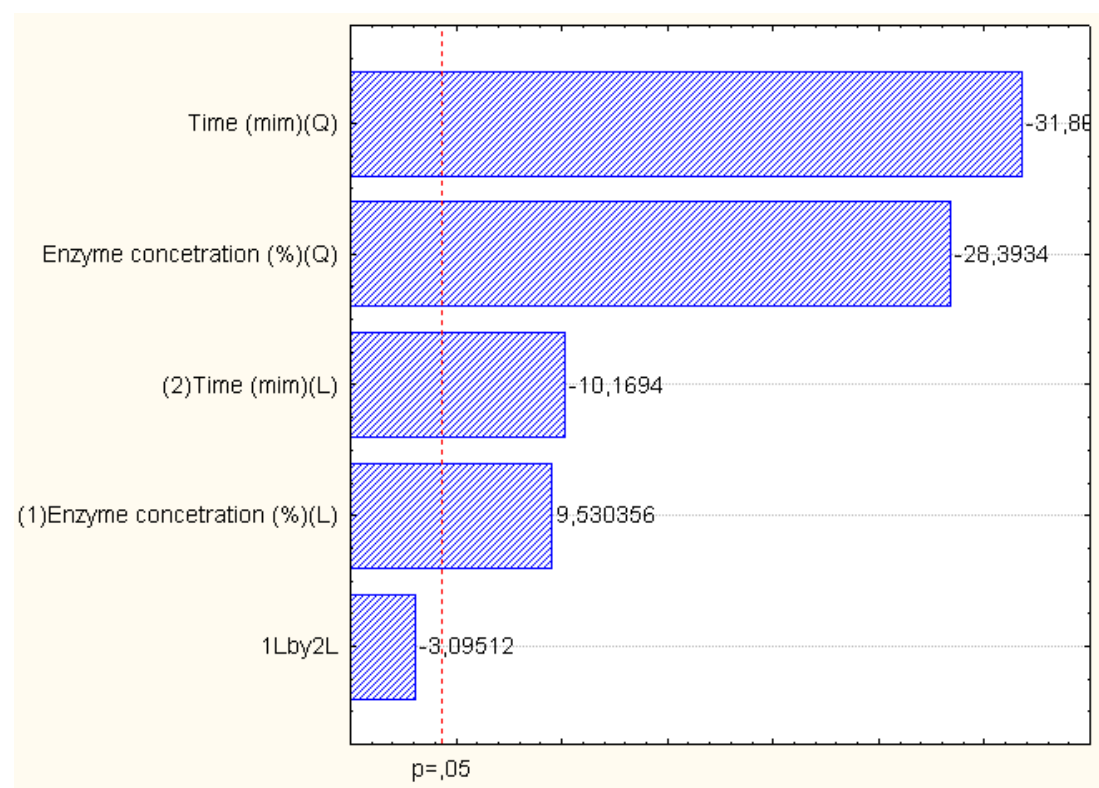

Fig. 11. Pareto Chart for inulin hydrolysis CCMB 300

The statistical significance (Table 06) e of the regression can be assessed by the ratio of the mean square regression and mean square of the residue and by comparing these sources of variation using the Fisher distribution ( $F$ test). Thus, a statistically significant value of this ratio must be greater than the tabulated value for $F$. It is obtained by the ANOVA table that calculated $F(103.46)$ is higher than the $F$ tabulated (9.01) showing that the function is well suited to the answers.

Table 06. Analysis of variance

\begin{tabular}{|c|c|c|c|c|c|c|}
\hline $\begin{array}{l}\text { Variation } \\
\text { source }\end{array}$ & SQ & gl & $\mathbf{M Q}$ & $\mathbf{F}$ & $\begin{array}{l}\text { Tabulated F } \\
\text { (IC de 95\%) }\end{array}$ & $\mathbf{R}^{2}$ \\
\hline Regression & 2859.761233 & 5 & 571.9522 & 103.4639 & 9.01 & \\
\hline Residual & 16.584105 & 3 & 5.528035 & & & \\
\hline Lack of Fit & 13.426 & 1 & 13.426 & 8.501 & 0.100253 & 0.99 \\
\hline Pure Error & 3.159 & 2 & 1.579 & & & \\
\hline Total SQ & 2876.345 & 8 & & & & \\
\hline
\end{tabular}

\section{CONCLUSION}

In this work the production and characterization of the inulinase by Pseudozyme sp. CCMB 300 was effectively performed. The enzyme was afterwards used in the hydrolysis of inulin, where a conversion yields of roughly $90 \%$ for an initial concentration of inulin of $1 \%(\mathrm{w} / \mathrm{v})$. Therefore, the inulinase from this yeast is a potential candidate for inulin hydrolysis in the food industry.

Using the response surface methodology it was possible to determine the best media composition for obtaining inulinase from Pseudozyme sp. This corresponds to a medium containing $0.86 \mathrm{~g} \mathrm{~L}^{-1}$ yeast extract and $14.54 \mathrm{~g} \mathrm{~L}^{-1}$ glucose. This statistical method was also used to access the optimum $\mathrm{pH}(8.28)$ and temperature $\left(54^{\circ} \mathrm{C}\right.$ for fermentative inulinase production.

The combination of results obtained in this work (enzymatic characterization and hydrolysis of inulin) can provide useful guidelines for the utilization of inulinase from CCMB 300 for fructose production at pilot scales.

This optimization through RMS can be used in future industrial scale fermentation in promoting the rational use of enzyme and substrate in the process. 


\section{REFERENCES}

[1]Gong, F., Zhang, T., Chi, Zhenming; Sheng, Jun, Li, Jing. Purification and characterization of extracellular inulinase from a marine yeast Pichia guilliermondii and inulin hydrolysis by the purified inulinase. Biotechnology and Bioprocess Engineering. 2009, 13, 533-539.

[2] Sharma, A., Aainth, A., Aill, A. A. Inulinase Production Using Garlic (Allium sativum) Powder as a Potential Substrate in Streptomyces sp. Journal of Food Engineering, 2006, 77, 486-491.

[3] Kochhar, A., Gupta, A.K., Kanur, N. 1999. Purification and immobilisation of inulinase from Aspergillus candidus for producing fructose. Journal of the Science of Food and Agriculture. 1999, 79, 549-554.

[4 ]Ricca, E., Calabro, V., Curcio, S., Loiro, G. The State of the Art in the Production of Fructose from Inulin Enzymatic Hydrolysis. Critical Reviews in Biotechnology, 2007, 27, 129-145.

[5] Figueiredo-Ribeiro, R.C.L., Pessoni, R.A.B., Braga, M.R. 2007. in: N. Shiomi; N. Benkeblia; S. Onodera. (org.). Recent advances in fructooligosaccharides RESEARCH. 1 ed. Kerala: research sign post press 18: 339-356.

[6]Uetanabaro, A.P.T.; Góes-Neto, A. 2006. In: Towards greater knowledge of the Brazilian semi-arid biodiversity. 1st ed. Brasília, DF. Ministério da Ciência e Tecnologia, pp 41-43.

[7] Lima, D.M, Oliveira, R.Q., Uetanabaro, A.P.T., Góes-Neto, A., Rosa, C.A., Assis, S.A Thermostable inulinases secreted by yeast and yeast-like strains from the Brazilian semi-arid region. International Journal of Food Sciences and Nutrition. 2009, 7, 63-71.

[8] Patching, J.W. and Rose, A.H. The effect and control of temperature. International Journal of Food Sciences and Nutrition. 1969, 2, 23-38.

[9] Miller, G.L. 1959. Use of Dinitrosalicylic Acid Reagent for Determination of Reducing Sugar. Analytical Chemistry, 3 , 426-428.

[10] Bradford, M.M. A rapid and sensitive method for the quantitation of microgram quantities of protein utilizing the principle of protein-dye binding. Analitical Biochemistry. 1976, 72, 248-254

[11] Nakamura, T., Ogata, Y., Shitara, A., Nakamura, A., Ohta, K. Continuous production of fructose syrups from inulin by immobilized inulinase from Aspergillus niger mutant 817 Journal of Fermentation and Bioengineering. 1995,80 (2), 164-169.

[12] Pandey, A., Soro Socco, L.C.R., Selvakumar, P., Soccol, V.T. Recent developments in microbial inulinases. Applied Biochemistry Biotechnology. 1999, 81, 35-52.

[13] Kango, N. Production of inulinase using tap roots of dandelion (Taraxacum officinale) by Aspergillus niger. Journal of Food Engineering. 2008, 85, 473-478.

[14] Chen, Q., Chen, X.M., Li, Y., Wang, J., Jin, Z.Y., Xu, X.M.. Purification and characterisation of exo- and endoinulinase from Aspergillus ficuum JNSP5-06. Food Chemistry. 2009. 115, 599-604.

\section{Author' biography with Photo}

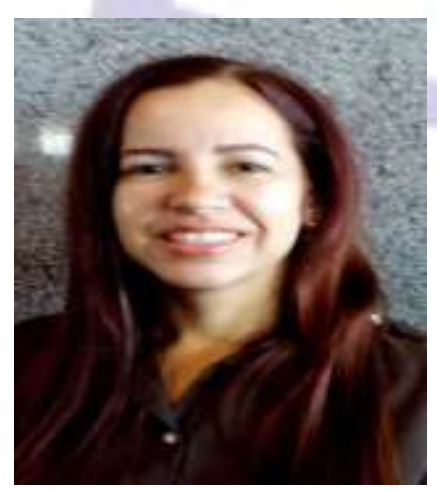

Graduated in biochemistry pharmacy by the Universidade Estadual Paulista Júlio de Mesquita Filho ( 1998 ), has Master degree in Biotechnology from the Universidade Estadual Paulista Júlio de Mesquita Filho (2000) and PhD in Biotechnology from the Universidade Estadual Paulista Júlio de Mesquita Filho (2004). She is currently professor of the State University of Feira de Santana. Has experience in the area of biochemistry , with an emphasis on enzymology, currently acting on the following topics : enzymes, biopolymers, carotenoids. The keywords that represent their lines of research are: plants, yeasts, enzymes, industrial applications, thermal stability, purification, biopolymers and pigments , application and extraction. Now is Coordinator of the Graduate Program in Biotechnology (PPGBiotec ) of the State University of Feira de Santana. 